\title{
TEMPERATURE IMPACT OF NITROGEN TRANSFORMATION IN TECHNOLOGICAL SYSTEM: VERTICAL FLOW CONSTRUCTED WETLAND AND POLISHING POND
}

\author{
Sylwia MYSZOGRAJ ${ }^{1}$, Franciszek BYDAŁEK ${ }^{1}$ \\ University of Zielona Gora, Institute of Environmental Engineering
}

\begin{abstract}
The article describes the results of the research, purpose of which was to evaluate influence of the temperature on the effectiveness of nitrification and denitrification in the sewage treatment system consisting of vertical flow constructed wetland and polishing pond. During the analysed period, the efficiency of removing total nitrogen was low and amounted to $12.7 \%$. In the polishing pond in the summer period, content of total nitrogen in treated sewages was further decreased by nearly $50 \%$. In the winter period, the polishing pond fulfilled mainly retention role and thus did not improve effectiveness of the whole system. Temperature coefficients, calculated on the basis of single first-order kinetics, for nitrification process in the filter bed $\left(\mathrm{N}^{-\mathrm{NH}_{4}}{ }^{+}\right)$and denitrification process in the polishing pond $\left(\mathrm{N}^{-\mathrm{NO}_{3}}{ }^{-}\right)$amounted to 1.039 and 1.089 , respectively.
\end{abstract}

Keywords: constructed wetlands, temperature, nitrogen removal, first-order kinetics

\section{INTRODUCTION}

For many remote communities, due to economic and topographic constrains, constructed wetlands $(\mathrm{CW})$ are a perfect alternative for centralized sewage systems based on septic tanks or sewerage, improving living standard. However, decentralizing of wastewater management aims not only for improvement of sanitation safety but also reduction of pollution discharge into the water bodies.

${ }^{1}$ Corresponding author: University of Zielona Gora, Institute of Environmental Engineering, Szafrana st 15, 65-246 Zielona Góra, tel. +48683282574, e-mail: s.myszograj@iis.uz.zgora.pl 
In many areas, domestic wastewater is a primary source deteriorating quality of local water resources, with nitrogen discharge being one of the main environmental concerns. Constructed wetlands offer wide range of removal mechanisms and can be pollution targeted designed, thus are widely used to limit excessive nitrogen leaching into the environment $[11,17,22]$. Due to the design characteristic (smallest land area required) and easy operational maintenance, vertical flow constructed wetlands (VFCWs) are very popular among home owners. Unlike other types of subsurface flow constructed wetlands, VFCW are less vulnerable to clogging and engage more plant interaction [7]. Transformation of nitrogen compounds in VFCW is dependent on several factors such as temperature, redox conditions, substrate material and sewage composition [7]. Further increase in effectiveness can be obtained through applying advanced operation strategies that include baffled flow, microbial fuel cells, bioaugumentation, artificial aeration or supply of electron donors [21]. Construction characteristic that enhances air-substrate gas exchange makes VFCW well aerated systems predominantly with aerobic zones. Oxygen enters VFCW filter bed through suction effect made by downwards water flow as well as plant input. Hence, in terms of nitrogen removal, VFCWs are dominated by oxygen - based nitrogen transformation processes. Even though VFCW are most efficiently oxygen-supplied wetland systems, several attempts were made to artificially enhanced oxygen content within filter bed. Simple air pump systems [5], eventual evolved into highly efficient oxygen supply systems such as force bed aeration VFCW [1]. When supplying VFCW with wastewater rich in organic nitrogen, ammonification process is activated, occupying top, highly aerated layers of filter bed. As a result, availability of $\mathrm{NH} 4$ drives nitrification process, predominantly carried out by autotrophic nitrifies, however heterotrophic nitrifies can also be involved [18]. High alkalinity of wastewater $(\mathrm{pH}>9.3)$ can lead to conversion of $\mathrm{NH}_{4}{ }^{+}$into $\mathrm{NH}_{3}$ and thus removal of ammonia through volatilization, however this process is insignificant for VFCW [12]. Also dissimilatory nitrate reduction, has not been reported to play any major role in VFCW, unlike in HFCW [18]. Ammonium can also be effectively incorporated into biomass, with rates in some cases taking over nitrification process [16]. Cation exchange phenomenon can temporarily inactivated $\mathrm{NH}_{4}{ }^{+}$transformation, when proper substrate media is used. Nevertheless, over the time absorbed ammonium is further utilize for nitrification process or biomass assimilation. Proper design and operational strategies, can promote anaerobic ammonium oxidation combined with vertical flow systems [3]. Ammonium transformation route may also include completely autotrophic nitrate removal over nitrate (Canon process) which can significantly improve VFCW effectiveness [15]. Even though, nitrogen-related process in VFCWs are mostly recognized for ammonium transformation routs, nitrate-based denitryfication can occur as well, although advanced approach is 
needed to facilitate the process otherwise it would have relatively low impact $[8,9]$. Both nitrate and ammonium, are converted into organic forms to form organic cells and tissues thorough plant uptake and microbial assimilation. Gaseous form of nitrogen $\left(\mathrm{N}_{2}\right)$ can be converted to ammonia, however that transformation process is rather negligible in VFCWs [18].

The main objective of this paper is to show the seasonal variability of transformation of nitrogen in most popular, commercially available type of vertical flow constructed wetland in Poland. Additionally the temperature coefficient with the first-order kinetic model was determined.

\section{METHODOLOGY}

\subsection{Research object}

The research object was a constructed wetland in Lubusz Voivodeship, which was created on the basis of solution patented by Applicable Ecology Institute [The Patent Office of Republic of Poland, No. 198680]. The treatment system realised the project of building of sewage treatment systems in the borough, subsidized by the Rural Development Programme for 2007-2013. Sewage treatment system is a system consisting of interconnected elements: $2 \mathrm{~m}^{3}$ polythene sedimentation tank, collector/pumping station with a submersed pump, and uplifted root filter connected by a drainage system with a polishing pond (Fig. 1). The root filter is a system of 3 filtering layers: $20 \mathrm{~cm}$ top layer of grinded pine bark, $50 \mathrm{~cm}$ middle layer of medium sand, $20 \mathrm{~cm}$ bottom layer of washed river gravel of $20-50 \mathrm{~mm}$ granulation. Common sedge (Carex niagra) grows on the surface of the filter. The structure of the filter is uplifted $90 \mathrm{~cm}$ over the ground, which enables gravitational discharge of treated sewages to the polishing pond. The filter bed is isolated form the ground with a foil of $2 \mathrm{~mm}$ width. The pond is isolated up to the height of $60 \mathrm{~cm}$ above the bottom, enabling discharge of the treated sewages into the soil through the infiltration zone. The whole system takes up $49 \mathrm{~m}^{2}$, in which the filter takes up $31.5 \mathrm{~m}^{2}$ and the pond takes up $17.5 \mathrm{~m}^{2}$ (Phot. 1).

Based on water meters reading of a household, average daily surface overflow rate of the treatment system is $0.4 \mathrm{~m}^{3} / \mathrm{d}$ or $12.7 \mathrm{dm}^{3} / \mathrm{m}^{2} \cdot \mathrm{d}$ per $1 \mathrm{~m}^{2}$ of the filter bed. The filter bed is fed in the pressure system with pre-treated sewages from the sedimentation tank. Dosing of sewages is irregular and depends on the filling of the pumping station, in which the pump automatically insets itself after the tank $\left(\right.$ about $75 \mathrm{dm}^{3}$ ) has been filled. Thereby, the filter bed is fed from 5 to 6 times a day. 


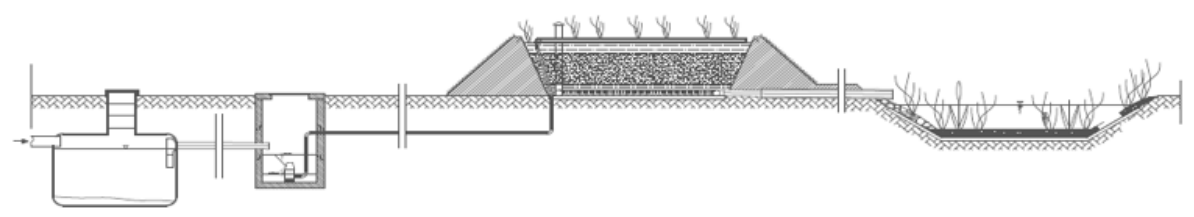

Fig. 1. Cross section of treatment system analyzed in the research [by Ecoverde, No. 198680]

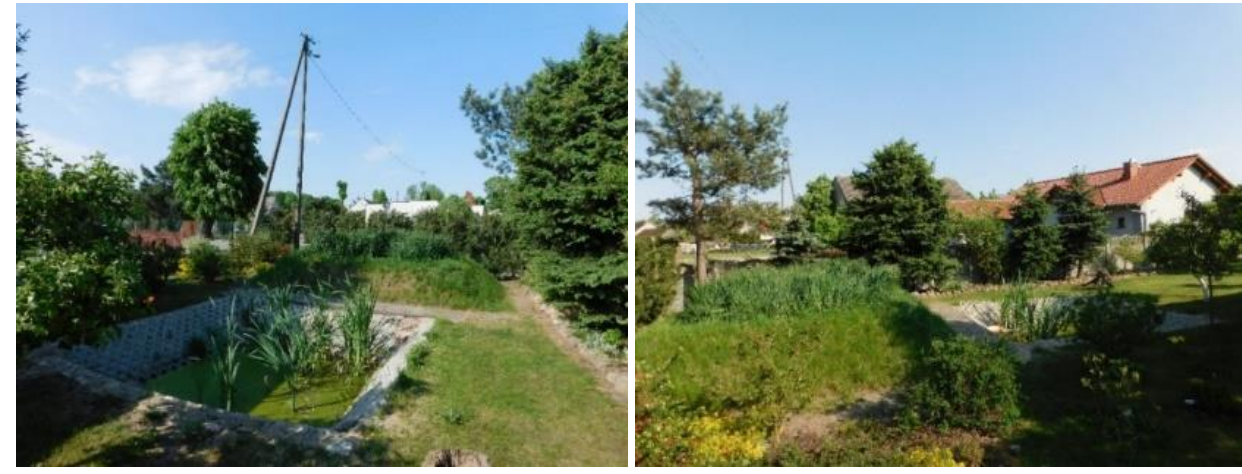

Phot. 1. View on the constructed wetland system [by Bydałek]

In the analysis of the research results, the water balance of the wetland including precipitation and evapotranspiration was not included, since:

- Average precipitation for the area in which the treatment system is located [6] amounts to about $575 \mathrm{~mm} / \mathrm{m}^{2}$ per year, which with the territory of treatment system taking $49 \mathrm{~m}^{2}$ gives about $29 \mathrm{~m}^{3}$ of precipitation per year;

- Evaporation from water surfaces very varied depending on the region of Poland and air temperature. The literature $[2,6]$ gives ranges from $500 \mathrm{~mm} / \mathrm{m}^{2}$ per year to even $1000 \mathrm{~mm} / \mathrm{m}^{2}$ per year, for Lubusz Voivodeship it is $500 \mathrm{~mm} / \mathrm{m}^{2}$ per year. Meanwhile, evaporation from surface covered in hydrophytes amounts to from $1000 \mathrm{~mm} / \mathrm{m}^{2}$ per year to even $2000 \mathrm{~mm} / \mathrm{m}^{2}$ per year [6]. Therefore, when considering minimal values of the evapotranspiration (500 and $1000 \mathrm{~mm} / \mathrm{m}^{2}$ per year), evapotranspiration of the analysed treatment plant amounts to about $33 \mathrm{~m}^{3} /$ year, thus being comparable to estimated precipitation.

\subsection{Analysis of effectiveness of sewage treatment}

Effectiveness of the treatment characteristic for the system was researched in a sewage quality monitoring system in three measuring points: raw sewages, sewages treated in the filter bed and sewages treated in the pond. The samples were collected in the period between August 2015 and January 2016. Before collecting samples, a pomp was connected to the filter bed and to the pond, forcing 
the feeding of fresh portion of sewages to the treatment system. Depending on the weather conditions, hydraulic retention time of the hydrophytic filter bed was between 10 and $15 \mathrm{~min}$. During sample collection, temperature of the sewages was measured at each measuring point, as well as air temperature and temperature at the depth of $30 \mathrm{~cm}$ inside the filter bed.

During 6 months, 16 samples total were collected, in 3 series:

- 5 samples in the period between August and September - summer period;

- 8 samples in the period between October and December - autumn period;

- 3 samples in the period between January 7 and 21 - winter period.

Due to exceptionally mild winter of 2015/2016, only 3 samples were collected in the period characterised by long periods of minus ambient temperatures.

Total Kiejdahl Nitrogen (TKN), ammonium nitrogen, nitrate nitrogen were marked in the sewage samples in compliance with applicable regulations.

\subsection{The first-order kinetic model of nitrogen removal applied to the VFCW}

The areal removal rate constant and the temperature coefficient were calculated from the monitoring data and the following first-order model [10, 13]:

$$
\operatorname{Ln}\left(\mathrm{C}_{\text {out }} / \mathrm{C}_{\mathrm{in}}\right)=-\mathrm{k}_{(\mathrm{T})} / \mathrm{q}
$$

where:

- $C_{\text {in }}$ and $C_{\text {out }}$ are the influent and effluent concentrations, respectively, in $\mathrm{mg} / \mathrm{dm}^{3}$,

- $\mathrm{q}$ is the hydraulic loading rate ( $\mathrm{m} / \mathrm{day})$,

- $\mathrm{t}$ is the temperature $\left({ }^{\circ} \mathrm{C}\right)$,

$-\mathrm{k}_{(\mathrm{T})}$ is the constant of a first-order removal rate on temperature ( $\mathrm{m} /$ day).

Equation (2) was used to calculate $\mathrm{q}(\mathrm{m} /$ day):

$$
\mathrm{q}=\mathrm{Q} / \mathrm{A}
$$

where:

- Q is total wastewater inflow rate $\left(\mathrm{m}^{3} /\right.$ day),

- A is the total area of the wetland $\left(\mathrm{m}^{2}\right)$.

The effect of temperature on the areal removal rate constant was modelled using the following equation:

$$
\begin{gathered}
\mathrm{k}_{(\mathrm{T})}=\mathrm{k}_{(20)} \cdot \Theta^{(\mathrm{T}-20)} \\
\operatorname{Lnk}_{(\mathrm{T})}=\operatorname{Ln} \Theta(\mathrm{T}-20)+\operatorname{Ln} \mathrm{k}_{(20)}
\end{gathered}
$$

Statistically significant differences were determined at the $\alpha=0.01$ significance level. 


\section{RESULTS AND DISCUSSION}

\subsection{Influent and effluent nitrogen concentrations}

Content of total nitrogen in raw sewages was on average $122 \mathrm{mgN} / \mathrm{dm}^{3}(\mathrm{n}=15)$ and stayed in the range from 100 to $140 \mathrm{mgN} / \mathrm{dm}^{3}$. The lowest values were observed in the winter period. Average content of total nitrogen in treated sewages was between 90 and $130 \mathrm{mgN} / \mathrm{dm}^{3}$. Effectiveness of sewage treatment was irregular. The lowest values of concentration of total nitrogen in pond water were observed in the summer period $\left(55-75 \mathrm{mgN} / \mathrm{dm}^{3}\right)$ and they were gradually increasing in the autumn period, stabilising at the level of $80-90 \mathrm{mgN} / \mathrm{dm}^{3}$ in the winter period. Ammonia nitrogen was the dominant (97\%) form of total nitrogen in raw sewages, reaching average value of $118.8 \mathrm{mgN}-\mathrm{NH}_{4}+/ \mathrm{dm}^{3}$. Sewage treatment in the hydrophytic filter bed lowered that value by $88 \%$. However, visible change of effectiveness of removing nitrogen was observed in comparison to the summer/autumn and winter periods. Content of $\mathrm{N}^{-\mathrm{NH}_{4}}{ }^{+}$in the effluent in the summer/autumn period was $9.1 \mathrm{mgN}-\mathrm{NH}_{4}{ }^{+} / \mathrm{dm}^{3}(\mathrm{n}=12)$ on average, while in the winter period over triple increase up to $30.9 \mathrm{mgN}-\mathrm{NH} 4^{+} / \mathrm{dm}^{3}(\mathrm{n}=3)$ was observed, which mirrors the decrease of effectiveness of mechanisms of removing ammonia nitrogen from the initial $92 \%(n=12)$ to $70 \%(n=3)$. Similar dependence was observed in the polishing pond, where content of ammonia nitrogen was highly correlated $\left(\mathrm{R}^{2}=77.2 \%, \mathrm{p}<0.05\right)$ with quality of fed sewages. Content of ammonia nitrogen in the pond was, on average, $20 \%$ lower than in treated sewages. Organic nitrogen in samples constituted from 1 to $5 \%$ of total nitrogen, which is indicator characteristic for this type of system. The lowest values were observed in treated sewages, which proves the effectiveness of ammonification process. Simultaneously, in the polishing pond could be observed increased level of nitrogen as compared to quality of sewages fed to it. Content of nitrogen in forms of nitrates in raw sewages was between 0.5 and $1.0 \mathrm{mgN}-\mathrm{NO}_{3}{ }^{-} / \mathrm{dm}^{3}$. Effective nitrification process happening in the hydrophytic filter bed caused the increase of content of nitrate nitrogen in the effluent to the level from 80 to $100 \mathrm{mgN}-\mathrm{NO}_{3} / \mathrm{dm}^{3}$ in the summer period $(\mathrm{n}=12)$. In the winter period decrease of $25 \%$ in the content of $\mathrm{N}^{-\mathrm{NO}_{3}}{ }^{-}$was observed, which coincides with the observations regarding effectiveness of removing ammonia nitrogen. Nitrate nitrogen constituted the dominant part of nitrogen in the polishing pond, wherein its' content fluctuated significantly in the range from 40 to $80 \mathrm{mg} \mathrm{N}-\mathrm{NO}_{3}{ }^{-} / \mathrm{dm}^{3}$, reaching minima in the summer and winter periods, while increased values were observed in the autumn period. 


\subsection{Effectiveness of the nitrification and denitrification process}

Effectiveness of the nitrification process in the hydrophytic filter bed during the period of the research presents Fig. 2. Between August and December, the effectiveness of oxidization of ammonia nitrogen was high: from 88 to $96 \%$. During that period, the temperature was gradually dropping due to change of seasons from 22 to $8^{\circ} \mathrm{C}$. In January, when the temperature in the filter bed dropped below $3{ }^{\circ} \mathrm{C}$, the efficiency of nitrification process gradually decreased to $65 \%$.

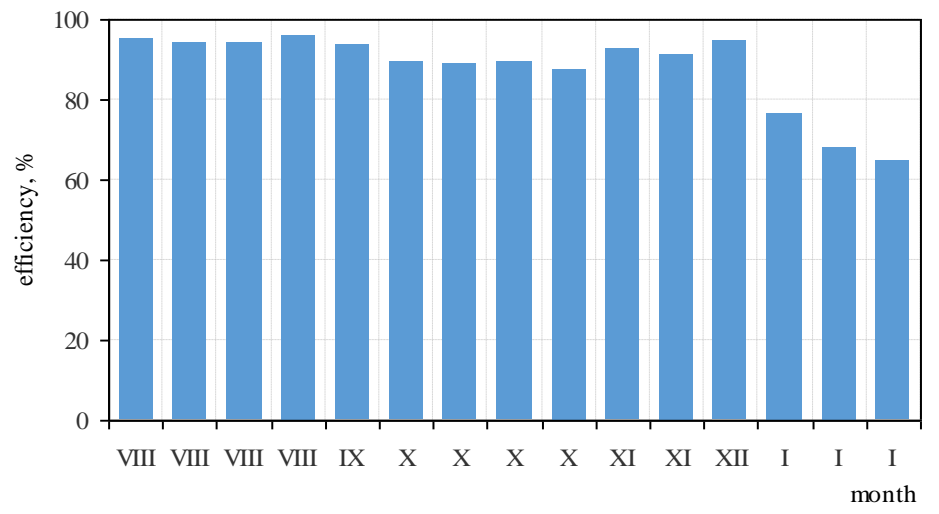

Fig. 2. Effectiveness of nitrification process

Effectiveness of denitrification process in the polishing pond during the period of the research presents Fig. 3. Between August and September, the effectiveness of reduction of nitrate nitrogen was from 40 to $65 \%$. From Oktober to beginning of January from 10 to $20 \%$. In January, it was found in the effluent from the pond higher concentration than in the treated wastewater.

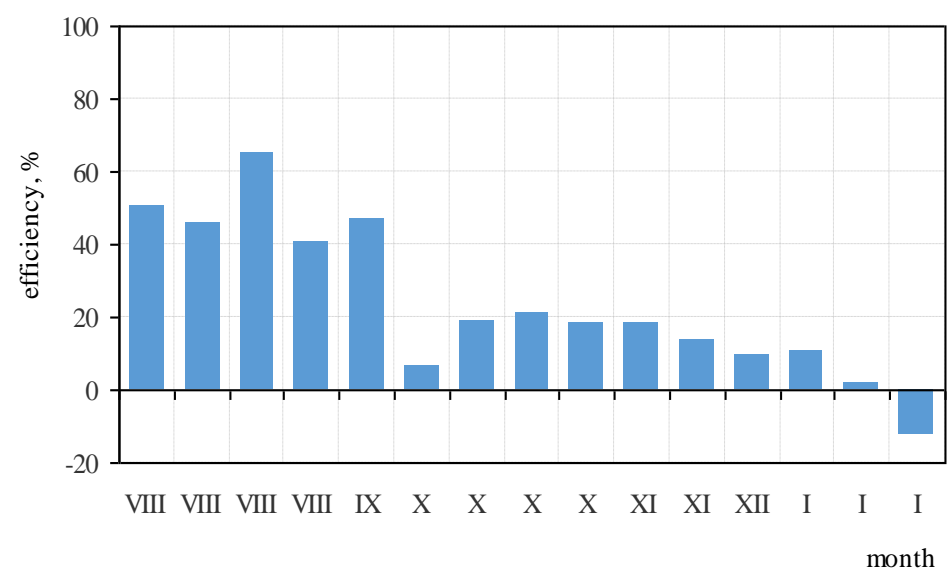

Fig. 3. Effectiveness of denitrification process 
The mechanism of transformation of nitrogen compounds in the hydrophytic filter bed and polishing pond system is proved also by the changes of $\mathrm{pH}$.

High significant correlation (Fig. 4) between $\mathrm{pH}$ of treated sewages and the effectiveness of removing ammonia ions $(\mathrm{R} 2=0.97, \mathrm{p}<0.001)$ was observed. Nitrification of $1 \mathrm{mg}$ of ammonia nitrogen uses up $7.14 \mathrm{mg}$ of basicity expressed with calcium carbonate $\left(\mathrm{CaCO}_{3}\right)$, whereas stoichiometrically, during the nitrification process of 1 mole of ammonia nitrogen, 1.98 mole of hydrogen ion $\mathrm{H}^{+}$is realeased, which leads to decrease of the $\mathrm{pH}$ [7]. The observed correlation proves, then, that nitrification proccess is the dominant mechanism of transformation of nitrogen compounds in the researched system, leading to acidification of the filter bed environment as a result. Observed decrease in effectiveness of nitrification in the winter period resulted in increase in $\mathrm{pH}$ of treated sewages amounting to nearly one degree.

Similar dependency, although not as much correlated $(\mathrm{R} 2=0.785, \mathrm{p}<0.001)$, was observed in the case of the polishing pond, where effectiveness of removing nitrogen compounds directly influenced $\mathrm{pH}$ of water (Fig. 5). This phenomenon shows influence of denitrification as a mechanism of removing nitrate nitrogen in the pond. Stoichiometric equation of denitrification shows that $1 \mathrm{mg}$ of oxidized nitrate nitrogen creates about $3 \mathrm{mg}$ of calcium carbonate, which results directly in the increase of $\mathrm{pH}$ [7]. Clearly, the decreased effectiveness of nitrification process in the winter period caused the decrease of water $\mathrm{pH}$ in the pond to the level close to the $\mathrm{pH}$ of treated sewages.

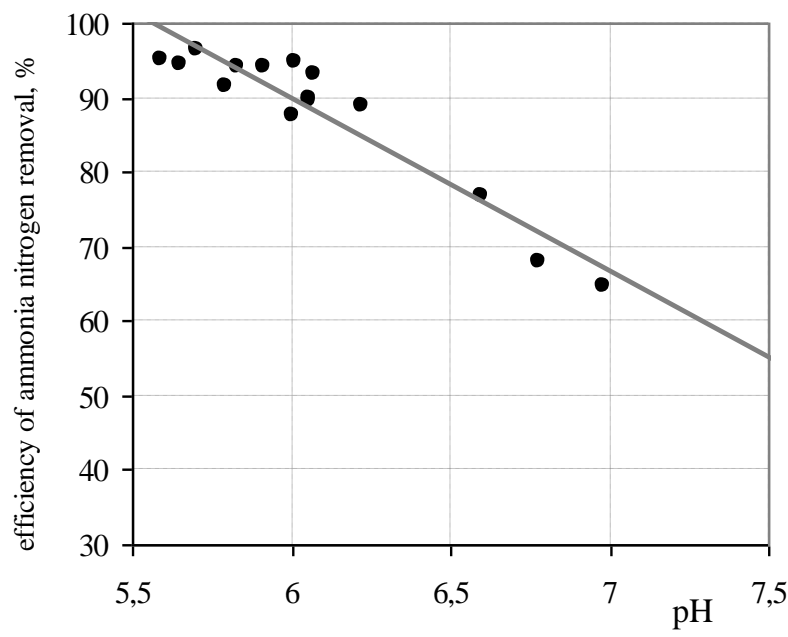

Fig.4 The impact of ammonium removal on $\mathrm{pH}$ of effluent 


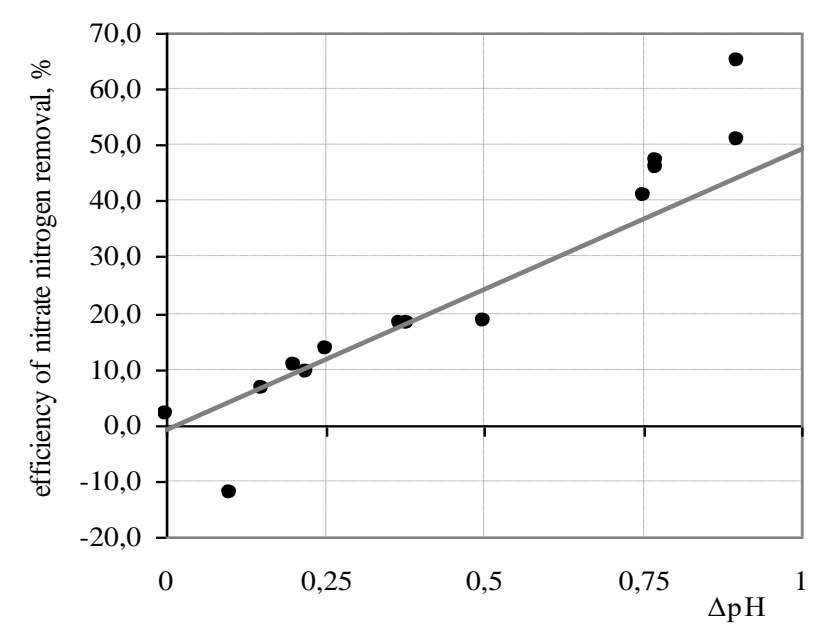

Fig. 5. pH neutralization effect based on removal effectiveness of nitrate in polishing pond

\subsection{Estimation of the temperature coefficients}

Using Equation (2.1) and the measured values of $\mathrm{C}_{\text {in }}$ and $\mathrm{C}_{\text {out }}$, were calculated constants $\left(\mathrm{k}_{(\mathrm{T})}\right)$ for $\mathrm{N}^{-\mathrm{NH}_{4}}{ }^{+}$and $\mathrm{N}^{-\mathrm{NO}_{3}}{ }^{-}$(Table 1). The corrected values of $\mathrm{k}_{(\mathrm{T})}$ for a temperature of $20^{\circ} \mathrm{C}$ and temperature coefficient were obtained from Equation (2.3).

Table 1. Calculated constants $\left(\mathrm{k}_{(\mathrm{T})}\right.$ and $\left.\mathrm{k}_{(20)}\right)$ and temperature coefficient $(\Theta)$ for nitrification and denitrification proccess

\begin{tabular}{|l|c|c|c|}
\hline \multicolumn{1}{|c|}{ constants } & $\mathrm{k}_{(\mathrm{T})}[\mathrm{m} / \mathrm{day}]$ & $\mathrm{k}_{(20)}[\mathrm{m} / \mathrm{day}]$ & $\Theta[-]$ \\
\hline Nitrification $(\mathrm{VFCW})$ & 0.030 & 0.038 & 1.039 \\
\hline Denitrification (polishing pond) & 0.007 & 0.012 & 1.089 \\
\hline
\end{tabular}

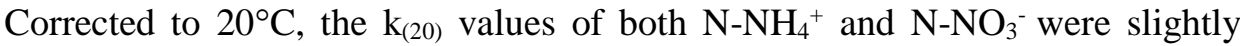
greater, indicating the influence of temperature on nitrogen removal. The $\mathrm{k}_{(20)}$ of $\mathrm{N}-\mathrm{NH}_{4}{ }^{+}$and $\mathrm{N}_{-} \mathrm{NO}_{3}{ }^{-}$were lower respectively, than those reported by the values obtained by Dzakpasu et al. [4]. The temperature coefficient $\Theta$ values estimated

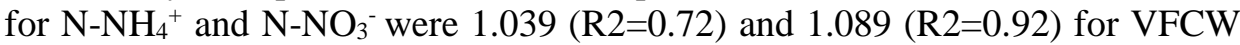
and for polishing pond, respectively, and were higher than those reported by Dzakpasu et al. [4].

\section{CONCLUSIONS}

Among a few mechanisms of removing nitrogen in VFCW sewage treatment systems, nitrification is the dominant process [19]. Meanwhile in vertical flow 
systems, nitrification process is often replaced by highly effective mineralisation of organic matter, which uses up majority of the available oxygen [14]. Practically, an effective nitrification happens only at depth below $40 \mathrm{~cm}$ [23], since in the higher part of the profile dominate processes of organic compounds oxidizing. VFCW systems are characterised by high level of aeration, however, in case of filling them with sewages containing high amount of organic matter or in case of clogging the filter, a considerable reduction of supplied oxygen happens. Literary data shows that effectiveness of nitrification in typical hydrophytic sewage treatment systems decreases rapidly in conditions below $10^{\circ} \mathrm{C}$ [7]. However, there are hydrophytic systems specifically adjusted to low temperatures that maintain high (over 70\%) effectiveness of removing nitrogen [24], which proves the possibility of maintaining biological mechanisms of removing nitrogen compounds in low temperatures. Thus, it can't be unequivocally determined that decrease in air temperature largely influenced the decrease in effectiveness of removing ammonia ions.

Based on the results, it was found that:

1. The mechanism of transformation of nitrogen compounds in the hydrophytic filter bed and polishing pond system was proved by the changes of $\mathrm{pH}$.

2. Temperature has an impact on the effectiveness of the processes of nitrification and denitrification in hydrophytic systems.

3. Greater influence of temperature on the transformation of nitrogen compounds was observed in the polishing pond than in the hydrophytic filter bed.

4. The temperature coefficient $\Theta$ values estimated for $\mathrm{N}_{-} \mathrm{NH}_{4}{ }^{+}$and $\mathrm{N}-\mathrm{NO}_{3}{ }^{-}$were 1.039 and 1.089 for $\mathrm{VFCW}$, and for polishing pond, respectively.

\section{REFERENCES}

1. Boog J. et al.: Hydraulic characterization and optimization of total nitrogen removal in an aerated vertical subsurface flow treatment wetland. Bioresource technology 162 (2014), 166-174.

2. Błażejewski R.: Kanalizacja wsi. PZiTS Oddział Wielkopolski, Poznań, 2003.

3. Dong Z., Tieheng S.: A potential new process for improving nitrogen removal in constructed wetlands - promoting coexistence of partial-nitrification and ANAMMOX. Ecological engineering 31.2 (2007) 69-78.

4. Dzakpasu, M., Hofmann, O., Scholz, M., Harrington, R., Jordan, S.N., McCarthy V.: Nitrogen removal in an integrated constructed wetland treating domestic wastewater. J. Environ. Sci. Health A. 46, (2011) 742-750.

5. Green M., Friedler E., Safrai I.: Enhancing nitrification in vertical flow constructed wetland utilizing a passive air pump. Water Research 32.12 (1998) 3513-3520. 
6. IMGW, http://www.imgw.pl.

7. KadlecR. H., Wallace S.: Treatment wetlands. CRC press, 2008.

8. Laber J., Perfler R., Haberl R.: Two strategies for advanced nitrogen elimination in vertical flow constructed wetlands. Water Science and Technology 35.5 (1997) 71-77.

9. Meuleman A. et al.: Water and mass budgets of a vertical-flow constructed wetland used for wastewater treatment. Ecological engineering 20.1 (2003) 31-44.

10.Myszograj S.: The impact of temperature on the removal of nitrogen compounds in activated sludge system., British Journal of Applied Science \& Technology, 11.1, (2015) 1-13.

11.O'Geen A. T. et al.: Chapter One-Mitigating nonpoint source pollution in agriculture with constructed and restored wetlands. Advances in Agronomy108 (2010) 1-76.

12.Reddy K. R., Patrick W. H., Broadbent F. E.: Nitrogen transformations and loss in flooded soils and sediments. Critical Reviews in Environmental Science and Technology 13.4 (1984) 273-309.

13.Rodríguez-Díaz J.M., Santos-Martín M.T.: Study of the best designs for modifications of the Arrhenius equation. Chemometrics and Intelligent Laboratory Systems. 95.2 (2009) 199-208.

14.Saeed T., Guangzhi S.: Kinetic modelling of nitrogen and organics removal in vertical and horizontal flow wetlands. Water research 45.10 (2011) 31373152.

15.Sun G., Austin D.: Completely autotrophic nitrogen-removal over nitrite in lab-scale constructed wetlands: Evidence from a mass balance study. Chemosphere 68.6 (2007) 1120-1128.

16.Sun G., Zhao Y., Allen S.: Enhanced removal of organic matter and ammoniacal-nitrogen in a column experiment of tidal flow constructed wetland system. Journal of biotechnology 115.2 (2005) 189-197.

17.Vázquez M. A. et al.: Vertical flow constructed wetland treating high strength wastewater from swine slurry composting. Ecological engineering 50 (2013) 37-43.

18.Vymazal J., Kröpfelová L.: A three-stage experimental constructed wetland for treatment of domestic sewage: first 2 years of operation. Ecological Engineering 37.1 (2011) 90-98.

19.Vymazal J.: Removal of nutrients in various types of constructed wetlands. Science of the total environment 380.1 (2007) 48-65.

20.The Patent Office of Republic of Poland, No. 198680 
21.Wu S. et al.: Development of constructed wetlands in performance intensifications for wastewater treatment: a nitrogen and organic matter targeted review. Water research 57 (2014) 40-55.

22. Yalcuk A., Ugurlu A.: Comparison of horizontal and vertical constructed wetland systems for landfill leachate treatment. Bioresource Technology 100.9 (2009) 2521-2526.

23. Ye J. et al.: Vertical oxygen distribution trend and oxygen source analysis for vertical-flow constructed wetlands treating domestic wastewater. Ecological Engineering 41 (2012) 8-12.

24.Zou X. et al.: Decreasing but still significant facilitation effect of cold-season macrophytes on wetlands purification function during cold winter. Scientific reports 6 (2016): 27011, doi:10.1038/srep27011.

\section{WPŁYW TEMPERATURY NA PRZEMIANY AZOTU W UKŁADZIE TECHNOLOGICZNYM: ZŁOŻE HYDROFITOWE O PRZEPŁYWIE PIONOWYM I STAW DOCZYSZCZAJĄCY}

\section{Streszczenie}

W artykule opisano wyniki badań, których celem była ocena wpływu temperatury na efektywność procesów nitryfikacji i denitryfikacji w przydomowej oczyszczalni ścieków pracującej w układzie: złoże hydrofitowe o przepływie pionowym i staw doczyszczający. W analizowanym okresie sprawność usuwania azotu ogólnego była niska i osiągała wartość $12,7 \%$. W stawie doczyszczającym w okresie letnim zawartość azotu ogólnego w ściekach oczyszczonych uległa dalszemu obniżeniu o blisko 50\%. W okresie zimowym, staw pełnił głównie rolę retencyjną, nie przyczyniając się do zwiększania efektywności pracy całego układu. Wyznaczony współczynnik temperaturowy $(\Theta)$ na podstawie założeń kinetyki pierwszego rzędu dla procesu nitryfikacji w złożu $\left(\mathrm{N}_{-} \mathrm{NH}_{4}{ }^{+}\right)$oraz denitryfikacji w stawie doczyszczającym $\left(\mathrm{N}^{-\mathrm{NO}_{3}}{ }_{3}{ }^{-}\right)$wynosił odpowiednio 1.039 i 1.089

Słowa kluczowe: oczyszczalnie hydrofitowe, temperatura, usuwanie azotu, kinetyka pierwszego rzędu

Editor received the manuscript: 23.04 .2016 